E-ISSN : 2549-6581

DOI: 10.21776/ub.JOIM.2020.004.03.5

Artikel Hasil Penelitian

Diterima : 6 Juli 2020

Direview : 7 Oktober 2020

Dimua t : Desember 2020 - Maret 2021

\section{OPEN ACCESS}

Journal of Issues in Midwifer

\title{
Hubungan antara Komunikasi lbu dan Anak, Pola Asuh Orang Tua, dan Sumber Informasi dengan Kesiapan Menghadapi Menarche pada Remaja Awal
}

\author{
Diyah Risnanda Nur Hanifah ${ }^{\left.1^{*}\right)}$, Mustika Dewi ${ }^{2}$, Yuseva Sariati ${ }^{2}$ \\ ${ }^{1 *}$ Program Studi S1 Kebidanan, Fakultas Kedokteran, Universitas Brawijaya \\ Email: diyahrisnanda@student.ub.ac.id, TIp: +6285655999496 \\ ${ }^{2}$ Program Studi Profesi Bidan, Fakultas Kedokteran, Universitas Brawijaya, Email: \\ mustikadewi@ub.ac.id ; sariatiyuseva@gmail.com
}

\begin{abstract}
Menarche is the first menstruation in women which indicates the maturity of a healthy woman and not pregnant. The first menstruation occurs at the age of 10-13 years, even in some children occurs faster so that children need to be prepared early to face menarche. There are at least $24 \%$ of students from 75 students who are not ready to face menarche. This unpreparedness can cause feelings of fear and confusion in the face of menarche. This study aims to find out whether there is a relationship between mother and child communication, parenting style, and sources of information with preparation for facing menarche in early adolescents. This study uses an observational analytic design with cross-sectional approach. The sample used was adolescents aged 10-12 years in SD Negeri Model Kota Malang who lived with mothers and had not experienced menarche. Data collection using questionnaire sheets and analyzed using chi-square test. The results of chi square analysis of communication variables mother and child obtained $p$ value $=0.00$, parenting styles variables obtained value $p=0.444$, and information source variables obtained $p$ value $=0.144$. This study concludes that there is a relationship between mother and child communication with readiness to face menarche in early adolescents and there is no relationship between parenting styles and the number of sources of information with readiness to face menarche in early adolescents.
\end{abstract}

Keywords: menarche, communication pattern, parenting style, information source

\section{ABSTRAK}

Menarche merupakan haid pertama kali pada wanita yang menandakan kedewasaan seorang wanita yang sehat dan tidak hamil. Haid pertama dapat dialami remaja saat usia 10-13 tahun atau justru dapat terjadi lebih dini sehingga anak perlu dipersiapkan secara dini untuk menghadapi menarche. Ketidaksiapan ini dapat menimbulkan perasaan takut dan bingung dalam menghadapi menarche. Penelitian ini memiliki tujuan untuk mengetahui adakah hubungan antara komunikasi ibu dan anak, pola asuh orang tua, dan sumber informasi dengan kesiapan menghadapi menarche pada remaja awal. Penelitian ini menggunakan rancangan observasional analitik dengan pendekatan cross sectional. 
Sampel berjumlah 75 remaja putri yang berusia 10-12 tahun di SD Negeri Model Kota Malang yang tinggal bersama ibu dan belum mengalami menarche. Teknik pengambilan sampel yang digunakan adalah simple random sampling. Pengumpulan data menggunakan lembar kuesioner dan dianalisis menggunakan uji chi square. Hasil analisis chi square variabel komunikasi ibu dan anak diperoleh nilai $p=0,00$, variabel pola asuh orang tua diperoleh nilai $p=0,444$, dan variabel sumber informasi diperoleh nilai $p=$ 0,144 . Kesimpulan dari penelitian ini yaitu terdapat hubungan antara komunikasi ibu dan anak dengan kesiapan menghadapi menarche pada remaja awal dan tidak ada hubungan antara pola asuh orang tua dan jumlah sumber informasi dengan kesiapan menghadapi menarche pada remaja awal.

Kata kunci: menarche, pola komunikasi, pola asuh, sumber informasi

`Korespondensi: Diyah Risnanda Nur H. Surel: diyahrisnanda@student.ub.ac.id

\section{PENDAHULUAN}

Remaja adalah seseorang yang berusia 10-18 tahun menurut Permenkes Nomor 25 tahun 2014. Fase ini merupakan fase perubahan dari anak-anak menuju dewasa. Perubahan fase ini ditandai dengan beberapa hal, salah satunya menarche pada remaja perempuan. Menarche atau haid pertama ini dapat dialami remaja mulai usia 1113 tahun, bahkan pada beberapa anak terjadi lebih dini. ${ }^{1}$ Lusiana dan Dwiriani $^{2}$ menemukan jumlah terbanyak siswi yang mengalami menarche pada usia 10-11 tahun $(86,7 \%), \quad 25$ siswi diantaranya $(41,7 \%)$ merasa takut ketika pertama kali mengalami menstruasi. Ketakutan yang dirasakan oleh siswi merupakan dampak dari ketidaksiapan. Selain ketakutan, ketidaksiapan juga dapat menyebabkan remaja sulit menerima yang berdampak pada sikap dalam merawat kemaluan (vagina) saat menstruasi. $^{3} \quad$ Kesiapan mengenai menarche meliputi aspek pemahaman, aspek penghayatan, dan aspek kesediaan. ${ }^{4}$ Aspek ini dipengaruhi oleh beberapa faktor yang diteliti secara terpisah dan belum banyak dijumpai seperti usia, sikap, sumber informasi, pengetahuan, pola asuh orang tua, dan komunikasi ibu dan anak. ${ }^{5}$ Sumber informasi merupakan bagian terbesar untuk menambah pengetahuan remaja mengenai menarche. Terdapat banyak sumber informasi yang dapat diakses siswi seperti dari internet dan media lainnya. Siswi juga dapat menerima informasi dari teman sebaya, sekolah, dan keluarga. Interaksi komunikasi pertama yang dilakukan oleh remaja adalah dengan keluarga, terutama ibu. Hal ini menjadikan keluarga sebagai sumber informasi pertama dan utama bagi remaja. Komunikasi ibu dan anak merupakan metode penyampaian dan penerimaan pesan diantara ibu dan anak yang terjadi secara langsung bertatap muka dan berlaku dua arah berikut adanya niat atau intense dari pihak yang berkomunikasi sehingga mampu menimbulkan respon dan umpan balik. ${ }^{6}$ Terdapat dua pola dalam komunikasi ibu dan anak, yaitu pola komunikasi fungsional dan pola komunikasi disfungsional. Dalam pola komunikasi fungsional pesan yang disampaikan secara jelas dan diterima dengan jelas oleh penerima pesan. Pola komunikasi disfungsional memiliki arti bahwa pengiriman dan 
penerimaan pesan serta perintah secara tidak jelas atau tidak bertatap muka.

Pola asuh orang tua merupakan metode orang tua berperan sebagai suatu aktivitas yang kompleks yang melibatkan banyak perilaku spesifik sebagai usaha yang aktif untuk mengarahkan anaknya. $^{7}$ Bentuk pola asuh yang diterapkan akan mempengaruhi kepribadian anak setelah menjadi dewasa. $^{8}$ Baumrind $^{9}$ menyebutkan bentuk pola asuh orang tua meliputi pola asuh permisif, pola asuh otoriter, dan pola asuh demokratis. Perbedaan jenis pola asuh yang diterapkan orang tua dipengaruhi oleh beberapa faktor, seperti kepribadian orang tua, keyakinan yang dimiliki orang tua, dan persamaan pola asuh yang diterapkan oleh orang tua dari orang tua.

Sumber informasi merupakan sumber-sumber yang dapat memberikan informasi mengenai menarche pada siswi. ${ }^{10}$ Kualitas informasi merupakan bagian penting untuk memberikan penilaian terhadap informasi yang diterima. McLeod dan Schell ${ }^{11}$ menyebutkan 4 aspek yang diperlukan untuk menambah nilai sebuah informasi, yaitu relevansi, akurasi, aktual, dan kelengkapan. Yusuf $^{12}$ mengatakan sumber informasi yang diterima siswi dapat diperoleh dari teman sebaya, lingkungan sekolah, dan keluarga.

\section{METODE PENELITIAN}

\section{Lokasi dan Rancangan Penelitian}

Penelitian dilakukan di SD Negeri Model Kota Malang. Rancangan penelitian ini merupakan penelitian observasional analitik dengan pendekatan cross sectional, yaitu dengan pengambilan data variabel independen dan variabel dependen diwaktu yang sama.

\section{Populasi dan Sampel}

Populasi dari penelitian ini adalah seluruh remaja putri berusia 10-12 tahun di SD Negeri Model Kota Malang. Pengambilan sampel menggunakan teknik simple random sampling pada siswi yang memenuhi kriteria inklusi yang sudah ditetapkan oleh peneliti, yaitu: (1) berusia 10-12 tahun terhitung sekurang-kurangnya 1 bulan sebelum penelitian; (2) bersedia mengisi kuesioner; (3) belum menstruasi; (4) tinggal bersama ibu. Jumlah sampel ditentukan dengan menggunakan rumus slovin dan diperoleh 75 sampel.

\section{Metode Pengumpulan Data}

Pengumpulan data dilakukan pada tanggal 17 Juli 2019 dengan memberikan lembar kuesioner yang sudah diuji validitas dan reliabilitasnya. Lembar kuesioner mengenai komunikasi ibu dan anak, sumber informasi, dan kesiapan menghadapi menarche diisi oleh siswi, sedangkan kuesioner mengenai pola asuh orang tua diisi oleh ibu siswi. 


\section{HASIL PENELITIAN}

Identifikasi Komunikasi Ibu dan Anak, Pola Asuh Orang Tua, Sumber Informasi, dan Kesiapan Siswi Menghadapi Menarche

Tabel 1. Identifikasi Komunikasi Pola Asuh Orang Tua, Sumber Informasi, dan Kesiapan Siswi Menghadapi Menarche

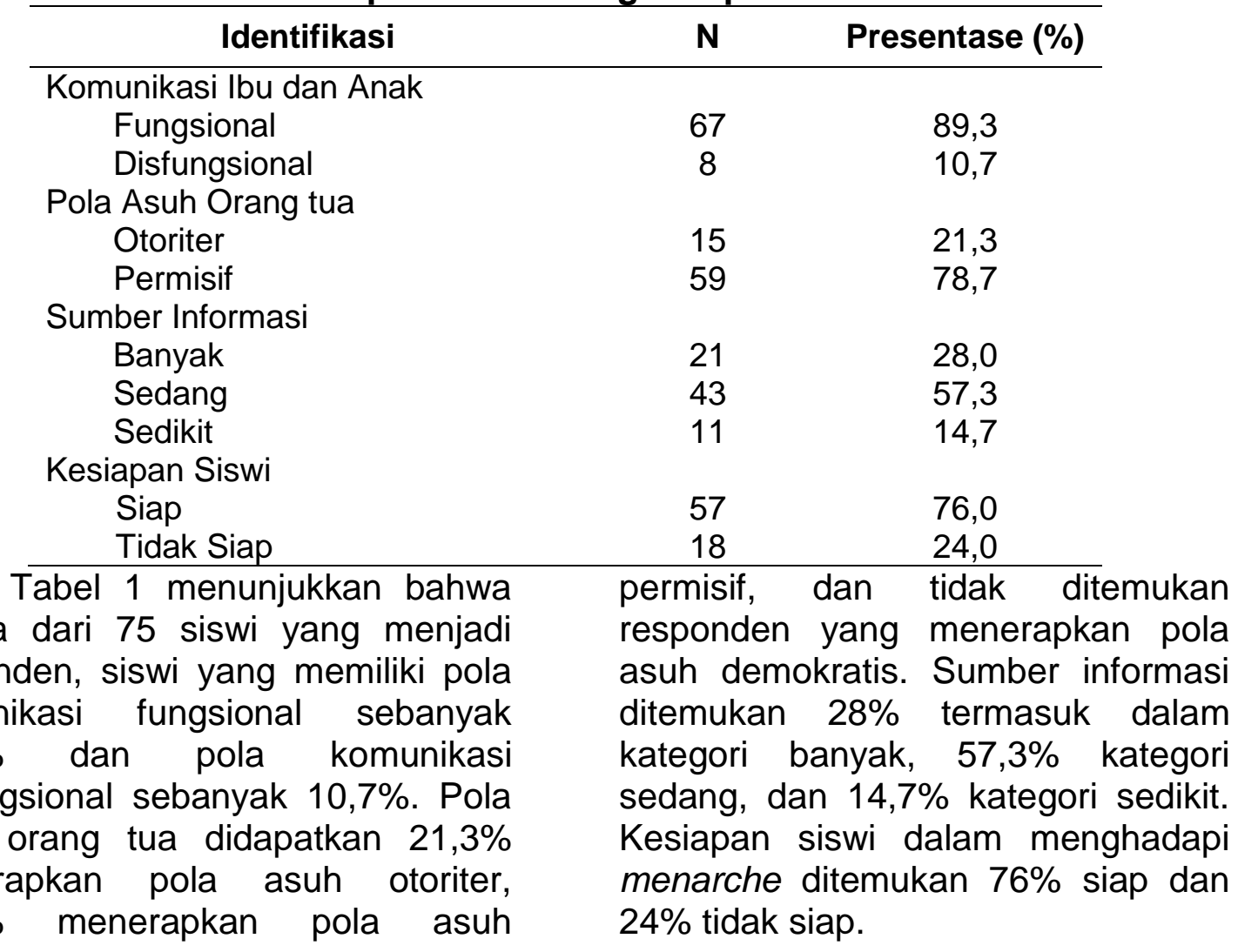

\section{Analisis Hubungan Komunikasi Ibu dan Anak dengan Kesiapan Remaja Awal Menghadapi Menarche}

Tabel 2. Tabulasi Silang Komunikasi Ibu dan Anak dengan Kesiapan

\begin{tabular}{ccccc}
\hline \multirow{2}{*}{ Pola Komunikasi Ibu dan Anak } & \multicolumn{5}{c}{ Kesiapan } \\
\cline { 2 - 5 } & \multicolumn{3}{c}{ Siap } & \multicolumn{3}{c}{ Tidak Siap } \\
\cline { 2 - 5 } & $\mathrm{F}$ & $\%$ & $\mathrm{~F}$ & $\%$ \\
\hline Fungsional & 56 & 74,7 & 11 & 14,7 \\
Disfungsional & 1 & 1,3 & 7 & 9,3 \\
Total & 57 & & 18 & \\
$p$ value & & 0,00 & & \\
\hline
\end{tabular}

Tabel 2 menunjukkan bahwa pola komunikasi dengan kategori fungsional sebanyak $74,7 \%$ lebih besar dibanding pola komunikasi disfungsional yaitu $1,3 \%$ pada siswi yang memiliki kesiapan dalam menghadapi menarche. Hasil $p$-value chi-square adalah 0,00 , yang berarti terdapat hubungan antara komunikasi ibu dan anak dengan kesiapan remaja menghadapi menarche. 


\section{Analisis Hubungan Pola Asuh Orang tua dengan Kesiapan Remaja Awal Menghadapi Menarche}

Tabel 3 Tabulasi Silang Pola Asuh Orang tua dengan Kesiapan

\begin{tabular}{ccccc}
\hline \multirow{2}{*}{ Pola Asuh Orang tua } & \multicolumn{4}{c}{ Kesiapan } \\
\cline { 2 - 5 } & \multicolumn{3}{c}{ Siap } & \multicolumn{3}{c}{ Tidak Siap } \\
\cline { 2 - 5 } Otoriter & $\mathrm{F}$ & $\%$ & $\mathrm{~F}$ & $\%$ \\
Permisif & 11 & 14,7 & 5 & 6,7 \\
Total & 46 & 61,3 & 13 & 17,3 \\
p value & 57 & & 18 & \\
\hline Tabel 3 menunjukkan bahwa & \multicolumn{3}{c}{ menarche. Hasil $p$ value chi square } \\
pola asuh dengan pola permisif & adalah 0,444, yang memiliki arti tidak \\
sebesar 61,3\% lebih besar dibanding & terdapat hubungan antara pola asuh \\
pola asuh dengan pola otoriter yang \\
hanya 14,7\% pada siswi yang
\end{tabular}
memiliki kesiapan dalam menghadapi

\section{Analisis Hubungan Sumber Informasi dengan Kesiapan Remaja Awal Menghadapi Menarche}

Tabel 4 Tabulasi Silang Sumber Informasi dengan Kesiapan

\begin{tabular}{ccccc}
\hline \multirow{2}{*}{ Sumber Informasi } & \multicolumn{4}{c}{ Kesiapan } \\
\cline { 2 - 5 } & $\mathrm{F}$ & $\%$ & $\mathrm{~F}$ & $\%$ \\
\hline Banyak & 18 & 24,0 & 3 & 4,0 \\
Sedang & 33 & 44,0 & 10 & 13,3 \\
Sedikit & 6 & 8,0 & 5 & 6,7 \\
Total & 57 & & 18 & \\
$p$ value & & 0,144 & & \\
\hline
\end{tabular}

Tabel 4 menunjukkan bahwa jumlah sumber informasi dengan kategori sedang sebesar $44 \%$ lebih besar dibanding dengan kategori banyak yaitu $24 \%$ dan kategori sedikit yaitu $8 \%$ pada siswi yang memiliki kesiapan dalam menghadapi menarche. Hasil $p$ value chi square adalah 0,144 , yang berarti tidak terdapat hubungan sumber informasi dengan kesiapan remaja menghadapi menarche.

\section{PEMBAHASAN}

Hubungan Komunikasi lbu dan Anak dengan Kesiapan Remaja Awal Menghadapi Menarche

Komunikasi memiliki arti bahwa pesan yang disampaikan secara jelas dan diterima dengan jelas oleh penerima pesan. Pola komunikasi ini memiliki karakteristik seperti adanya komunikasi emosional, area-area terbuka dari komunikasi dan membuka diri, hirarki kekuasaan dan aturan-aturan keluarga, konflik keluarga dan resolusi keluarga. ${ }^{13}$ Komunikasi yang efektif seperti ini setidaknya akan menimbulkan pengertian, pengaruh pada sikap, kesenangan, hubungan yang semakin baik, dan tindakan. Sebaliknya, komunikasi disfungsional memiliki arti pengirimian dan penerimaan pesan serta perintah yang tidak jelas atau tidak langsung. Penerima pesan tidak dapat menerima pesan secara jelas. Kedua pola komunikasi ini dapat mengarahkan perilaku remaja kearah 
positif maupun negatif. Hasil uji menyatakan terdapat hubungan antara komunikasi ibu dan anak dengan kesiapan remaja awal menghadapi menarche. Responden yang memiliki komunikasi yang efektif dan fungsional dengan ibunya lebih siap mengadapi menarche. Adanya komunikasi fungsional antara ibu dan anak memberi peluang untuk lebih terbuka dengan ibunya sehingga ibu dapat mengarahkan anaknya kearah yang positif. Terdapat $14,7 \%$ siswi dengan pola komunikasi fungsional yang tidak siap menghadapi menarche, 9 dari 11 siswi tersebut hanya memiliki 2 atau bahkan 1 sumber informasi yang tidak diketahui kualitasnya. Dalam penelitian juga ditemukan 1 sampel yang memiliki pola komunikasi disfungsional yang siap menghadapi menarche. Sampel ini memiliki sumber informasi yang mungkin kualitas informasinya baik yang dapat menambah pengetahuan siswi sehingga siap menghadapi menarche.

\section{Hubungan Pola Asuh Orang Tua dengan Kesiapan Remaja Awal Menghadapi Menarche}

Hasil pengolahan data menunjukkan pola asuh orang tua yang lebih banyak diterapkan yaitu permisif dibanding otoriter, bahkan tidak ditemukan orang tua yang menggunakan pola asuh demokratis yang membuat hasil penelitian berbeda. Perbedaan penerapan pola asuh yang ditemukan dilapangan dengan hasil penelitian milik Saputri ${ }^{14}$ disebabkan lokasi penelitian yang berbeda sehingga karakteristik orang tua juga berbeda. Perberdaan karakteristik orang tua membuat pola asuh yang diterapkan berbeda. Hasil uji menyatakan tidak terdapat hubungan antara pola asuh orang tua dengan kesiapan remaja awal menghadapi menarche. Tidak adanya hubungan dapat deikarenakan penilaian pola asuh orang tua dilakukan dengan kuesioner yang berisi pertanyaan global untuk menilai berbagai bentuk sikap orang tua dalam berbagai aktivitas kehidupan sehari-hari, bukan hanya terpusat untuk menyiapkan masa pubertas anak. Penyebab lain tidak adanya hubungan antara pola asuh dengan kesiapan adalah adanya faktor yang lebih dominan yaitu pengetahuan anak. Keluarga, terutama ibu merupakan sumber informasi terdekan dan utama bagi anak, sehingga keduanya harus memiliki komunikasi yang baik agar pesan yang disampaikan diterima dengan baik dan menambah pengetahuan anak. Baik responden dengan pola asuh otoriter dan permisif, keduanya mayoritas memiliki komunkasi yang fungsional dengan ibunya, dimana ketika anak bertanya maka ibu memberikan jawaban yang jelas dan benar sehingga anak lebih memahami dan siap menghadapi menarche.

\section{Hubungan Sumber Informasi dengan Kesiapan Remaja Awal Menghadapi Menarche}

Sumber informasi yang didapat oleh siswi akan memberikan pilihan untuk menentukan sikap, Ketika informasi yang tidak benar, maka siswi akan memiliki persepsi negatif terhadap menarche sehingga membuat siswi tidak siap menghadapi menarche. Benar tidaknya suatu informasi merupakan salah satu hal yang diperlukan untuk menambah nilai sebuah informasi. Semakin tingginya kuantitas informasi yang diterima siswi tidak menjamin tingginya taraf kesiapan menarche 
pada remaja awal. $^{15}$ Hasil uji menyatakan tidak terdapat hubungan antara sumber informasi dengan kesiapan. Hal ini dapat dikarenakan dalam penelitian ini tidak diamati bagaimana kualitas informasi yang diterima siswi. Kualitas informasi yang diterima siswi akan berpengaruh pada tingkat pengetahuan siswi sehingga juga berpengaruh pada tingkat pengetahuan siswi. Pengetahuna siswi inilah yang kemudian akan mempengaruhi bagaimana kesiapan siswi dalam menghadapi menarche.

\section{KESIMPULAN}

Kesimpulan yang diperoleh dari penelitian yang telah dilakukan adalah sebagai berikut:

1. Hasil pengolahan data menunjukkan dari 75 siswi yang menjadi responden, 57 responden $\quad(76,0 \%)$ siap menghadapi menarche. 67 responden $(89,3 \%)$ memiliki pola komunikasi fungsional dengan ibunya, 59 responden $(78,7 \%)$ menerapkan pola asuh permisif, dan 43 responden (57,3\%) kategori sedang atau mendapat 2 sumber informasi.

2. Terdapat hubungan antara komunikasi ibu dan anak dengan kesiapan menghadapi menarche pada remaja awal.

3. Tidak terdapat hubungan antara pola asuh orang tua dengan kesiapan menghadapi menarche pada remaja awal.

4. Tidak terdapat hubungan antara jumlah sumber informasi dengan kesiapan menghadapi menarche pada remaja awal.

\section{DAFTAR PUSTAKA}

1. Kementerian Kesehatan RI. 2012. Buku Petunjuk Penggunaan Media Kie. Jakarta.

2. Lusiana, S. A. And Dwiriani, C. M. 2007. Konsumsi Pangan, Dan Status Gizi Anak Perempuan Sekolah Dasar Di Bogor. Institut Pertanian Bogor, Pp. 26-35.

3. Setyaningsih, D., Indriyani, D. And Yulis, E. Z. 2015. Hubungan Persepsi tentang Menarche dengan Sikap Vulva Hygiene saat Menstruasi pada Remaja Putri di SMP Al-Badri Kecamatan Kalisat Kabupaten Jember, Pp. 1-12.

4. Yusuf, A. M. 2002. Pengantar IImu Pendidikan. Jakarta : Ghalia Indonesia

5. Fajri, A. dan Khairani, M. 2011. Hubungan Antara Komunikasi IbuAnak dengan Kesiapan Menghadapi Menstruasi Pertama (Menarche) pada Siswi SMP Muhammadiyah Banda Aceh. Jurnal Psikologi Undip, Pp. 133143

6. Haryono, Rudi. 2016. Siap Mengahdapi Menstruasi dan Menopause. Jogjakarta : Gosyen Publishing

7. Madyawati, Lilis. 2016. Strategi Pengembangan Bahasa pada Anak. Jakarta: Kencana

8. Djamarah, Syaiful B. 2014. Pola Asuh Orangtua dan Komunikasi dalam Keluarga: Upaya untuk Membangun Citra Membentuk Pribadi Anak. Jakarta: PT. Rineka Cipta.

9. Baumrind, D. 1967. Child Care Practices Anteceding Three Patterns of Preschool Behavior. Genetic Psychology Monographs, Pp 43-88.

10. Jayanti, S. P. 2012. Deskripsi Faktor-Faktor yang Mempengaruhi Kesiapan Anak dalam Menghadapi Menarche di SD Negeri 1 Kretek Kecamatan 
Kabupaten Brebes Tahun 2011, Bidan Prada:Jurnal IImiah Kebidanan, Pp. 1-14.

11. McLeod, Raymond and George P. Schell. 2008. Sistem Informasi Manajemen. Terjemahan oleh Ali Akbar Y. dan Afia R. Fitriani. Jakarta: Salemba Empat

12. Yusuf, S. 2010. Psikologi Perkembangan Anak Dan Remaja (Edisi Revisi). Bandung : PT. Remaja Rosdakarya

13. Friedman, M. M. 2003. Family nursing: research, theory, and practice. USA: Prentice Hall

14. Saputri, S. A. 2012. Hubungan Pola Asuh Orangtua dengan Tingkat Kecemasan pada Remaja dalam Menghadapi Menarche di SD Negeri Nayu 77 Surakarta. Karya Tulis IImiah. Surakarta : Universitas Sebelas Maret

15. Lutfiya, Indah. 2016. Analisis Kesiapan Siswi Sekolah Dasar dalam Menghadapi Menarche. Surabaya: Universitas Airlangga. Jurnal Biometrika dan Kependudukan, Pp 135-145 